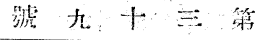

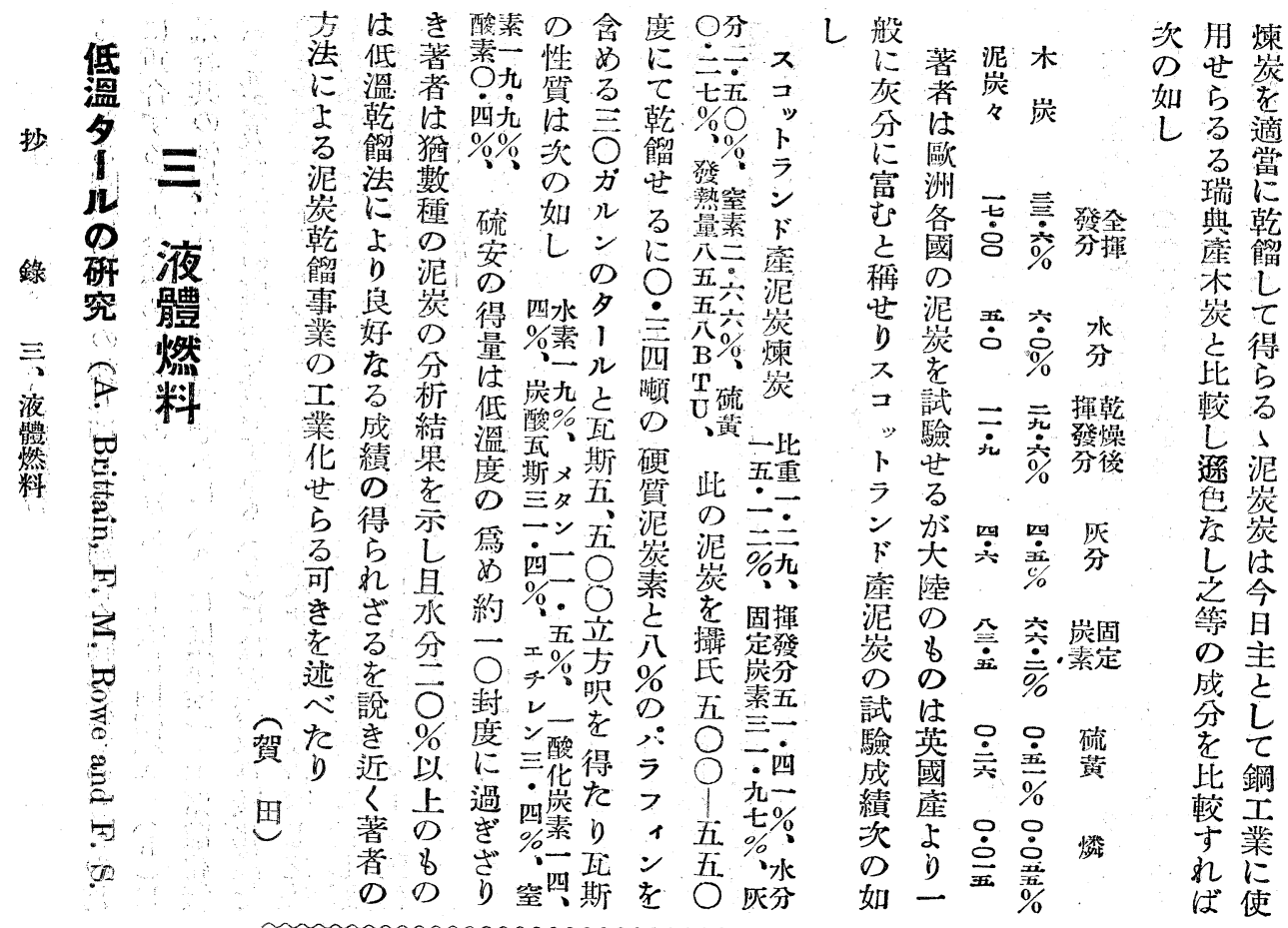

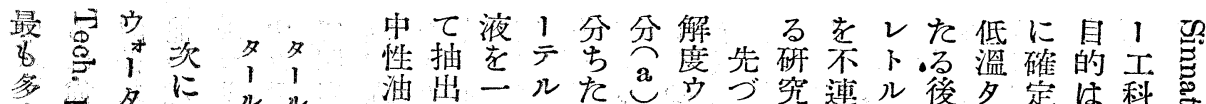

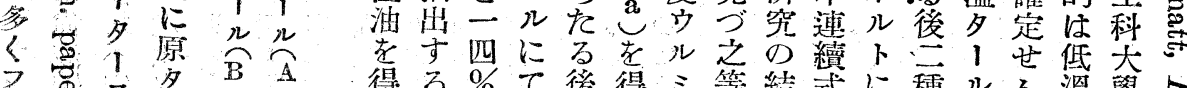

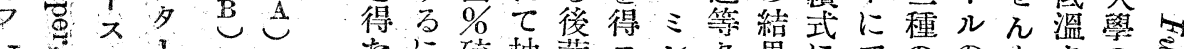

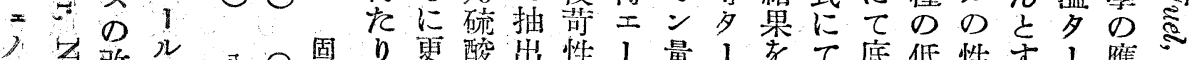

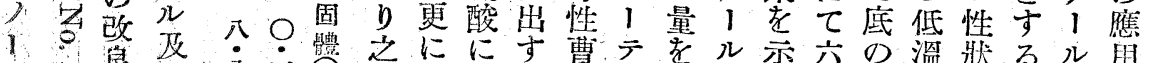

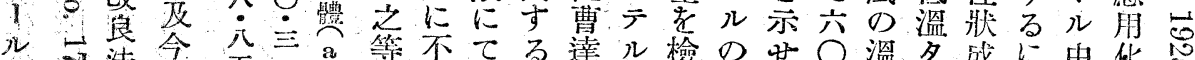

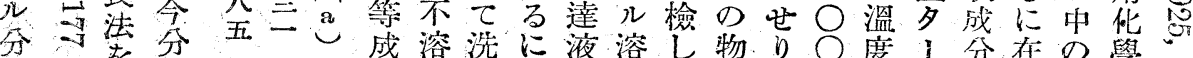

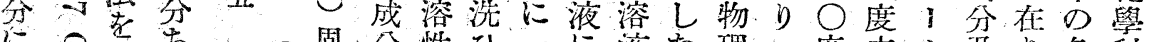

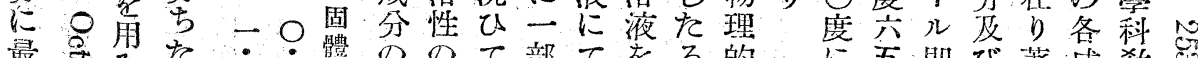

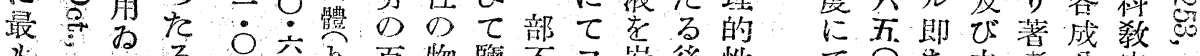

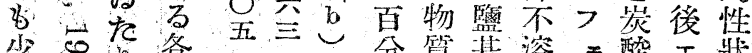
少苍

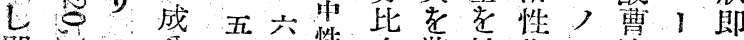
即已分四六性游抽物 1 趞示ち

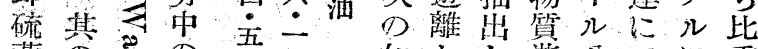
一 黃D兽の>如しし遊分てに重

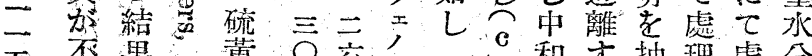

五不果凶黄? 空; 和主抽理處分

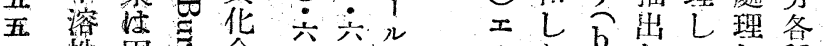
狌固合公類 1 た b

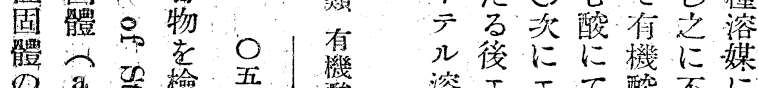

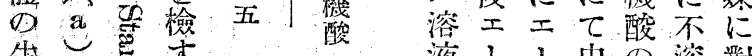
生汽等, 液 11 中心溶對 成

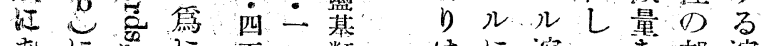

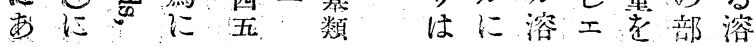
て 0 呆者分室。 乾度デにはを长 餾に几關先出於 してビす年來て 得た子從一文は的 たるイ來報け就可 る夕多市研變た本 小石究过字研 儿炭に雭し究

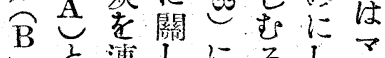

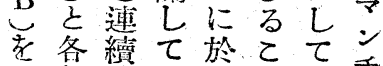
用種式略筧と研手

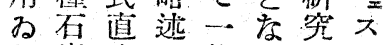
た炭立し航しの夕 
$\tau$ テ炭

分儿华第 沃比疋飽

别に水沓和

抽溶法郝

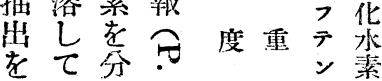

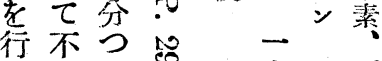

U 飽雼

た和に

万炭夕的

仁，於

原水儿元

油素 $\mathrm{A}$ 先

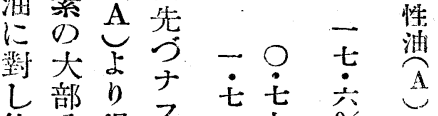

飽分得?

和老を

炭除万们

化を炭

水を化化

素石水水

之後素素

し液洤素

て 體走方

二 㰳 石

三硫油 フ

其证 1 ン
溶确零フル1と承固去含就にる 媒混度テコル閶素體灼主方き重重

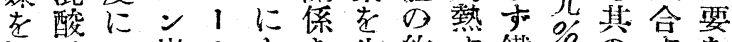
逐及て炭几よ市生約す鐵及灭のすな ひ扎順化其门らし六好は文性るる 出五沃氷の異儿て倍ば、微牀乙關

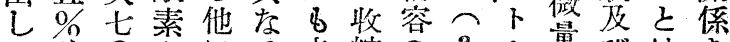

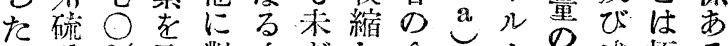

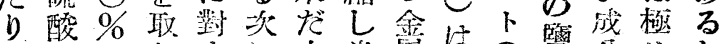

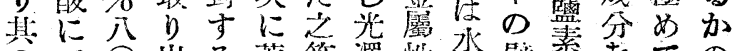

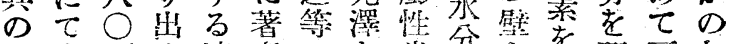

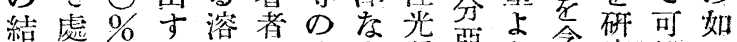

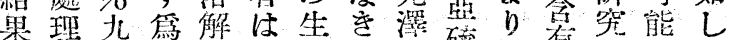
得し○に度中成脆の硫機傅せの卵

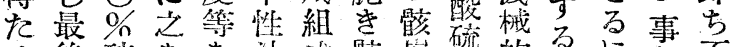

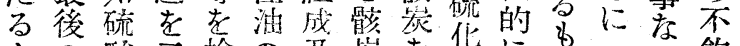

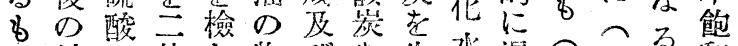
の油に倍し物びを生水混 $\widehat{b} \mathfrak{a}$ る和

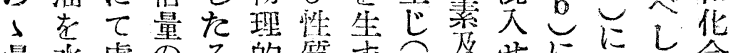

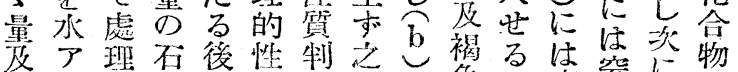

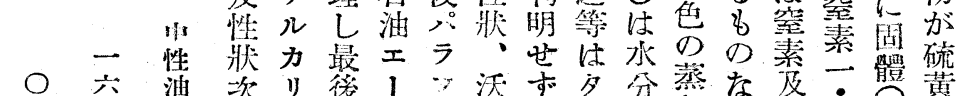

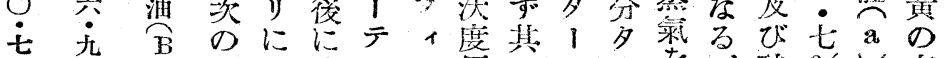
如し空ルン價のル，起酸\%存 して溫に及及量ピル墢し化酸 古在 筧に溶びび る

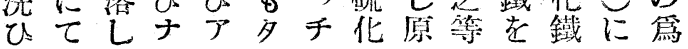

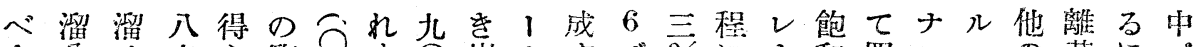

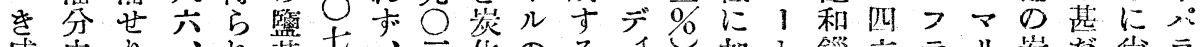

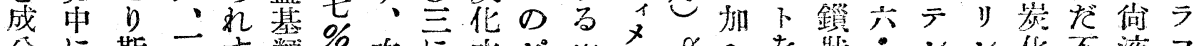

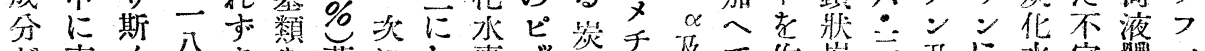

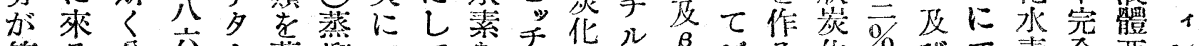

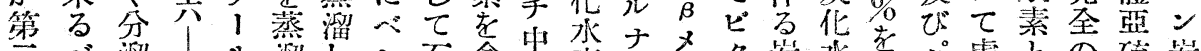

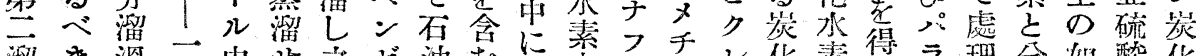

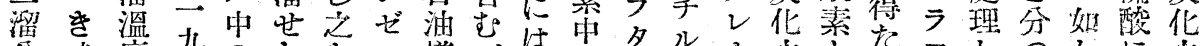

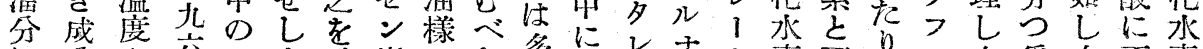

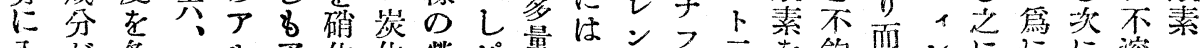

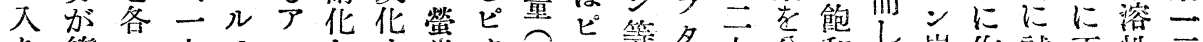
り 第>九カ

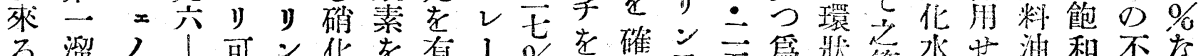

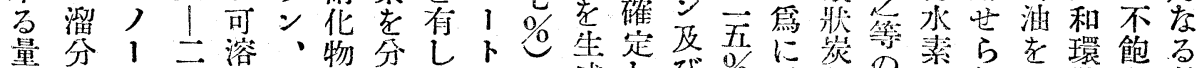

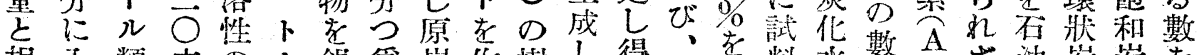

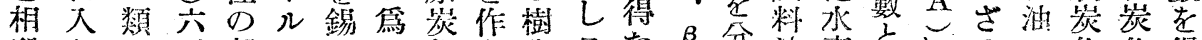
殺りの、部イとに化ら脂易た分油素之にる工化化得

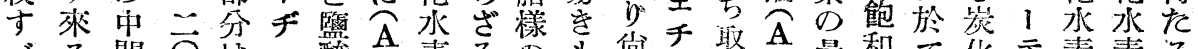

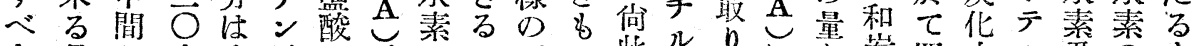

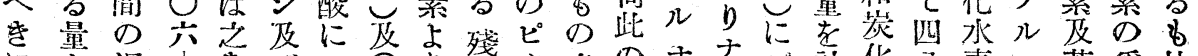

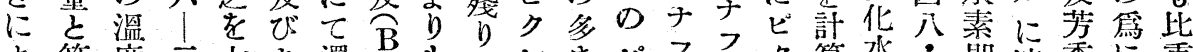
上第度三七キ還

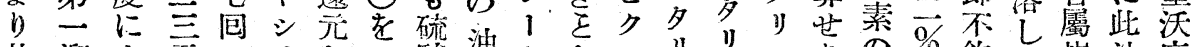

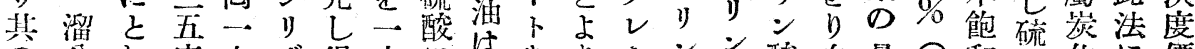

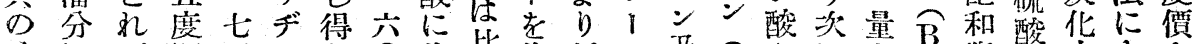

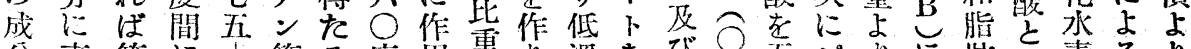

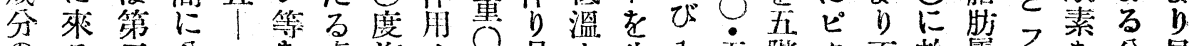

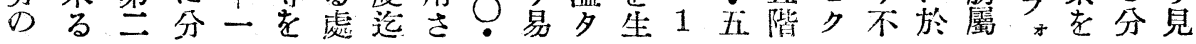

\section{$\longrightarrow$ 五.}




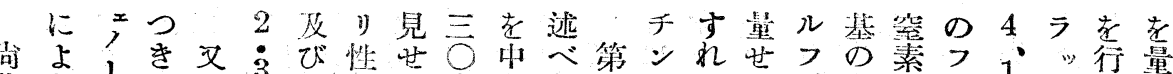

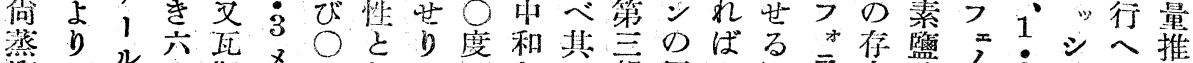

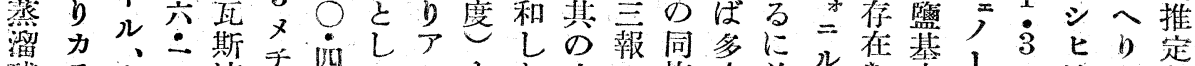

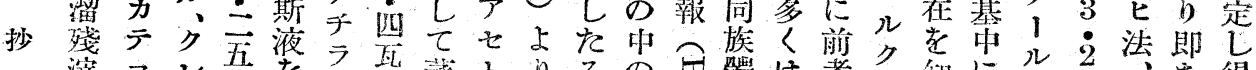

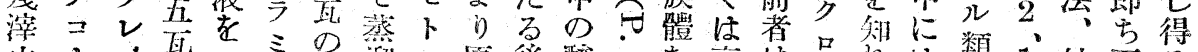

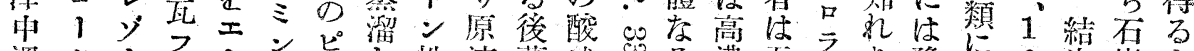

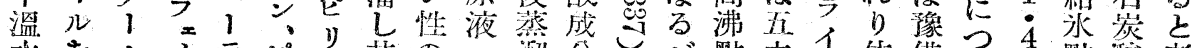

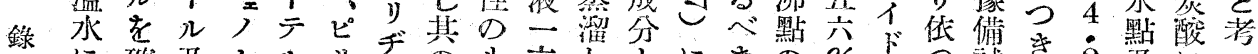

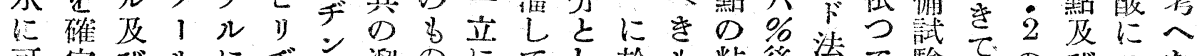
可定びルにヂ稫溜のにてし於も粘後法て驗でのでうた

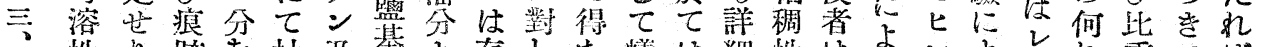

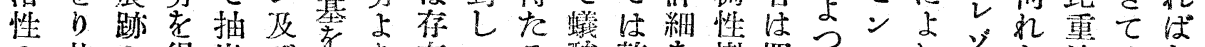
の其の得出び得り在 $\bigcirc$ る酸畭な樹四てス行法はな

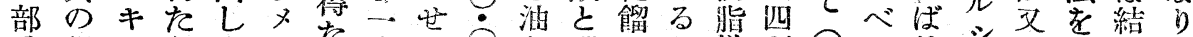

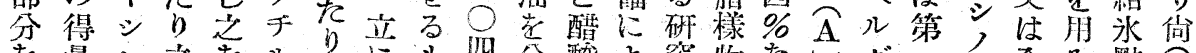

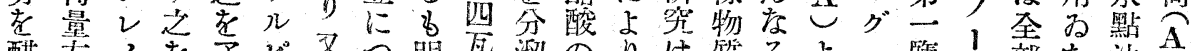

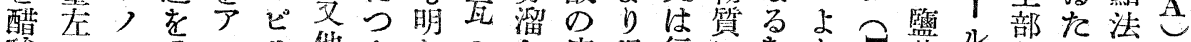

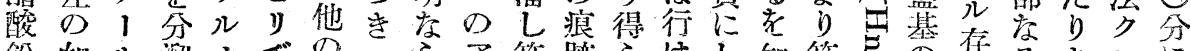
鉛如儿溜カデの 方ア第跡らはし知第吉劣存るキレに

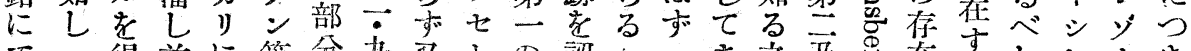

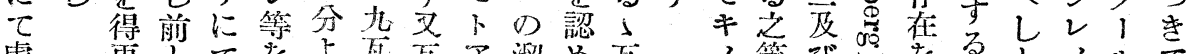

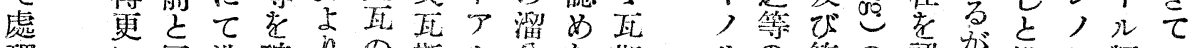
理に同犎確りの斯ル分た斯》の第の認が推１類は

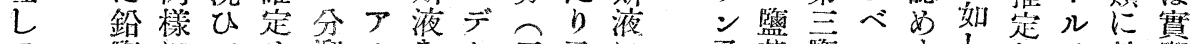

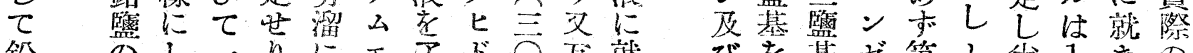

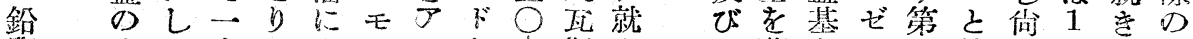

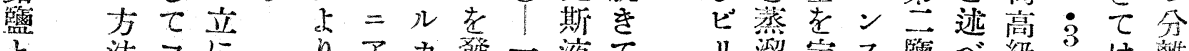

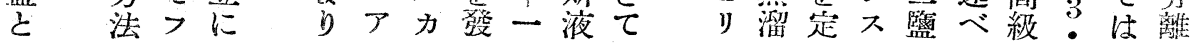

佛六普の四1の10ン得ク成に

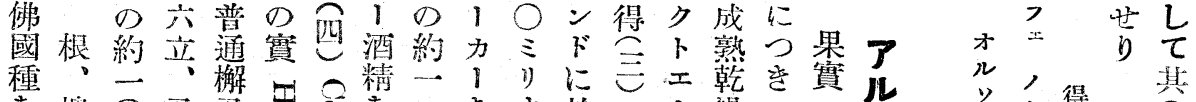

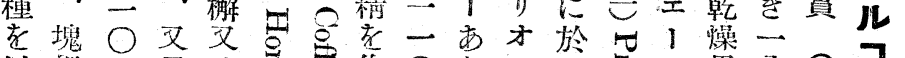

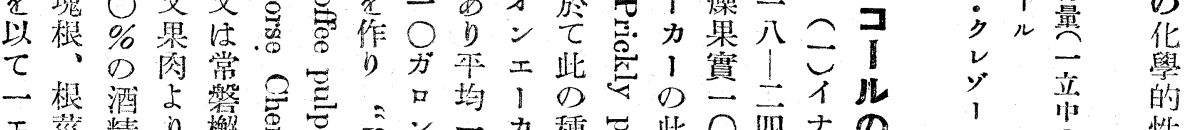

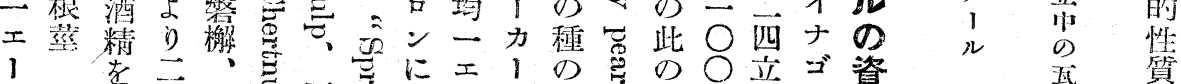

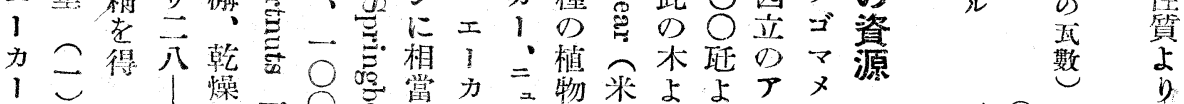

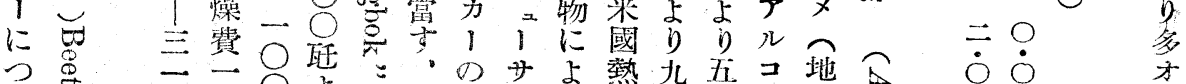

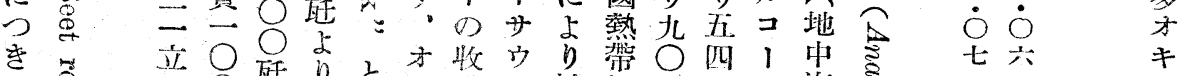

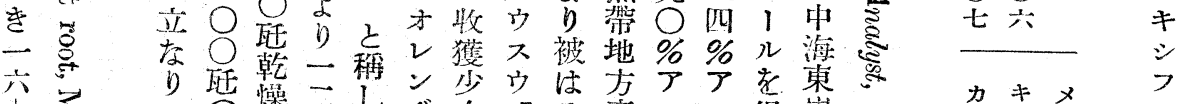

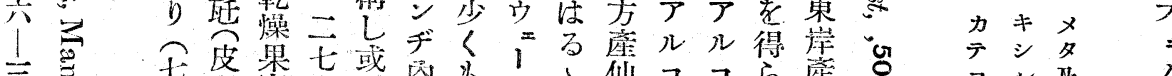

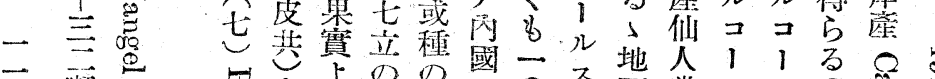

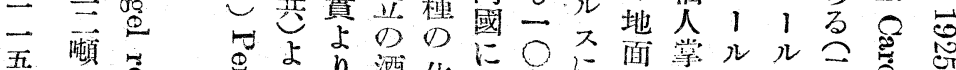

七の过

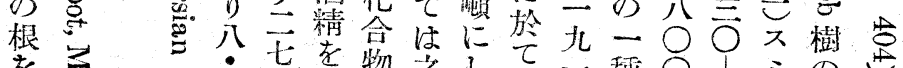

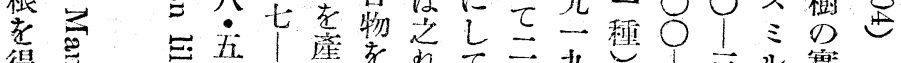

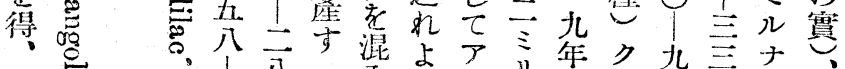

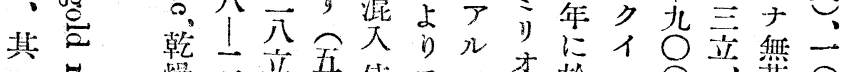

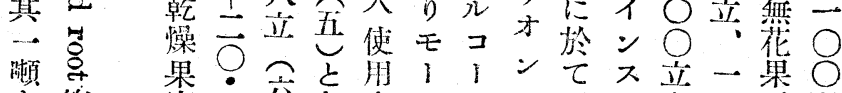

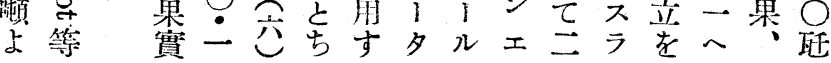

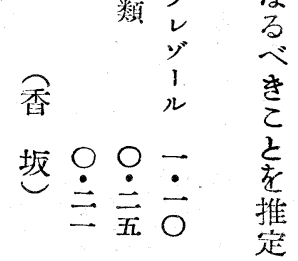




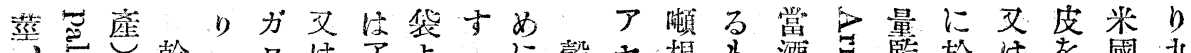

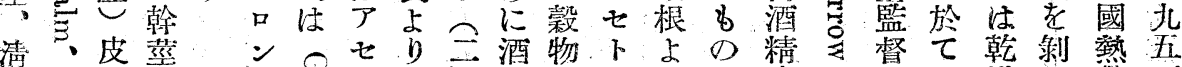

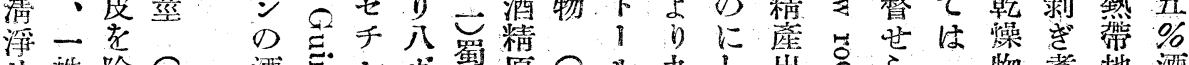

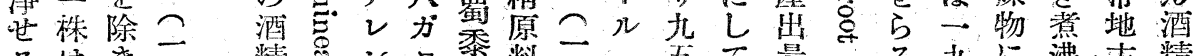

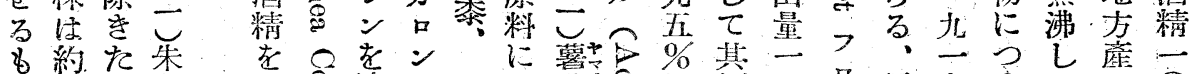

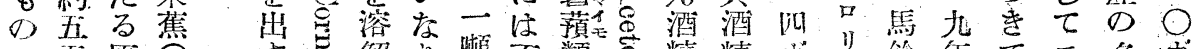

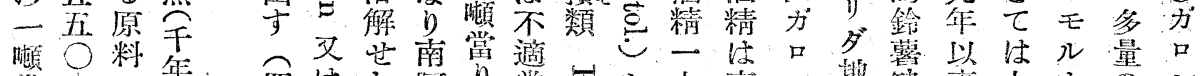

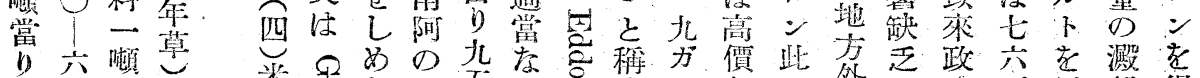

昆五

\% 班㤱 酒度五音 精粗 \% \&

二製酒又

吾洪精文

召䎦杂言

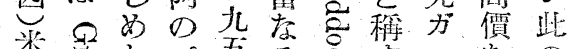

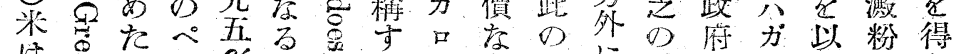

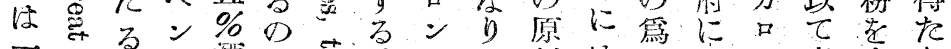

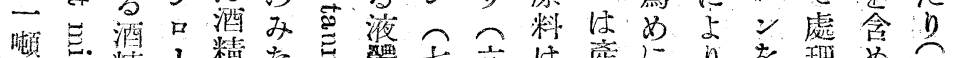

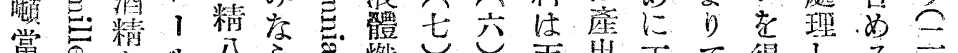

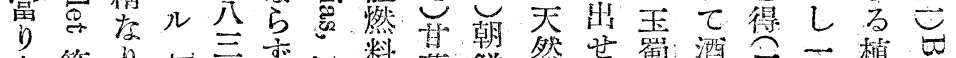

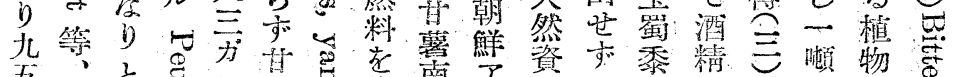

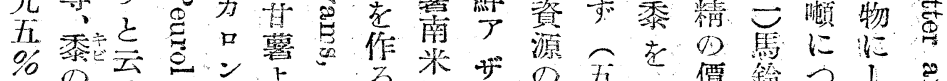

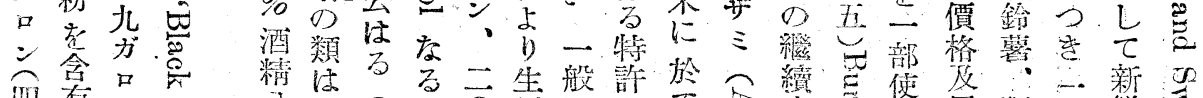

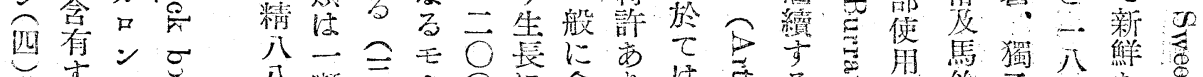

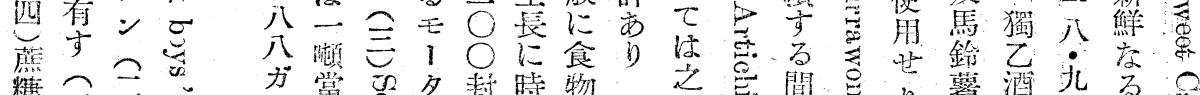

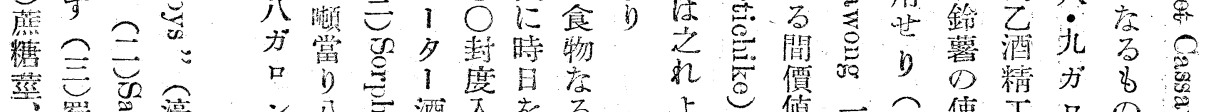

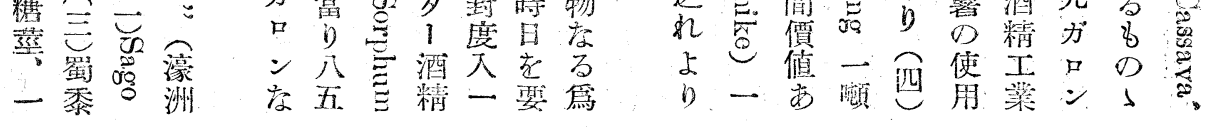

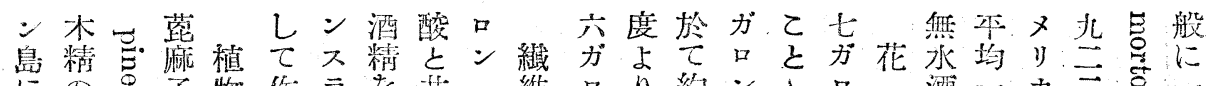

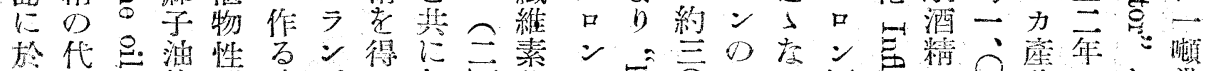

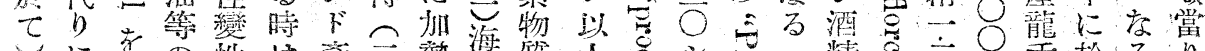

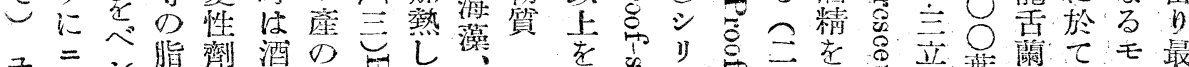

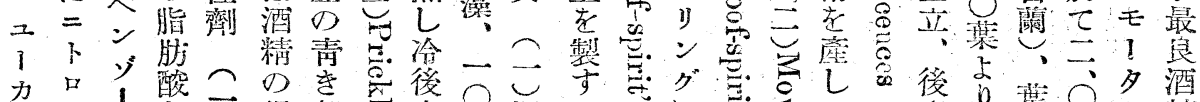

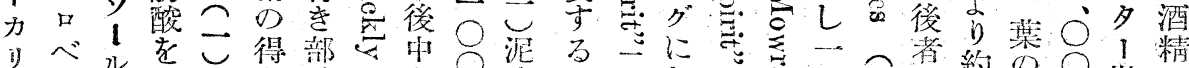

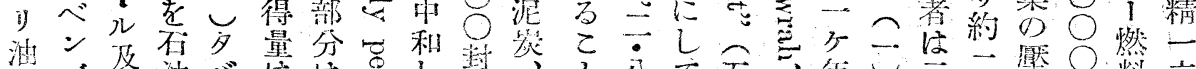

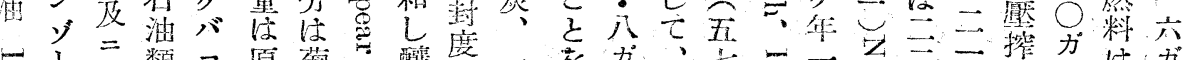

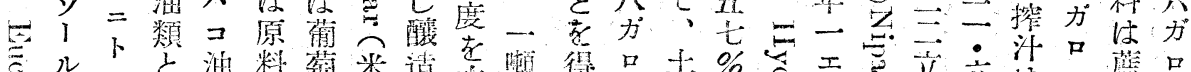
几

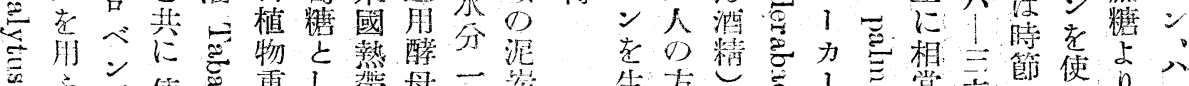

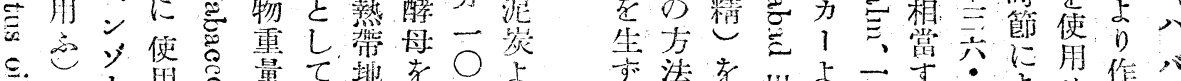

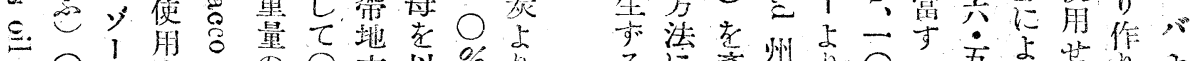
二四儿寸。元 0 方以 $\%$ b

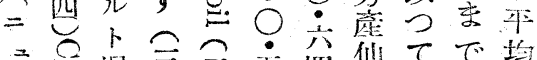

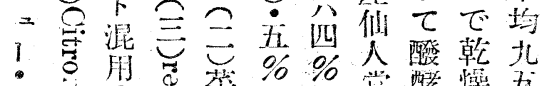

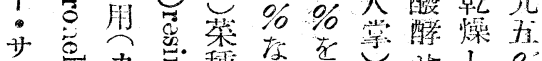

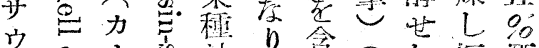
ウき。商油り含のし短酒

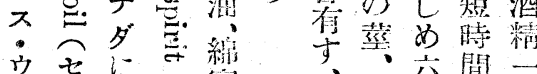
ウ七に䋩 エイテス賽注ク立椎五 万结呈州方合

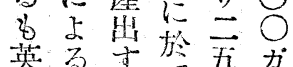
國時畭 $\tau \bigcirc$ には燥年ガン 短乾花七控 乙筑 - 0 二 汁 作花獺老上 万公篗 0 鏟 1口はは油意イ硫力 時二地○寸六 は政に○る。 五卡毕子 其元に五 耀震五方綡 $\equiv$
三
液
體
然
粼 錄 
りの三吹其ら些溜移分以のに之類法殊利三分、，ル

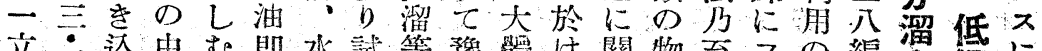

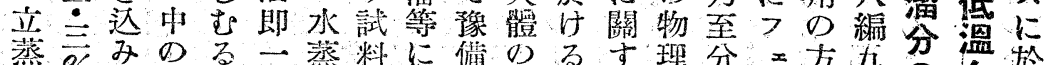

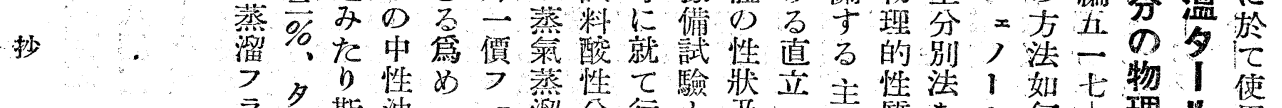
ラ夕斯油一匹溜分行之炎々要筫を儿何理儿角

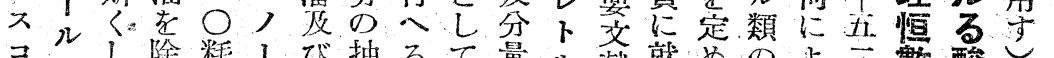

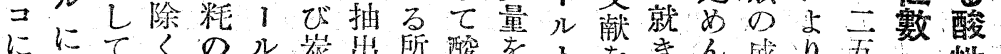

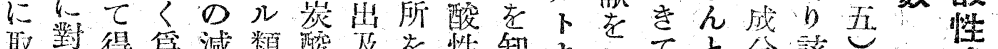

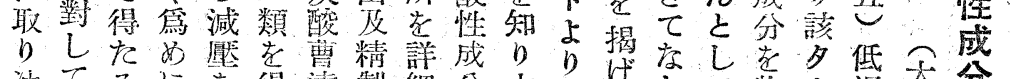
波てるにを得澾製細分本得けして物1溫大分

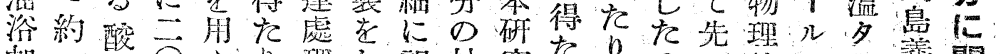

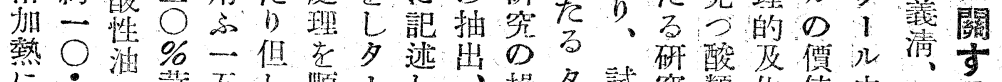

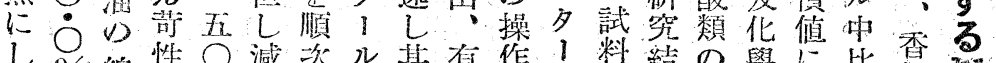

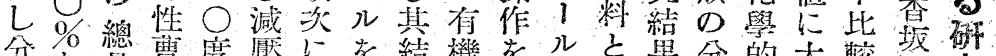

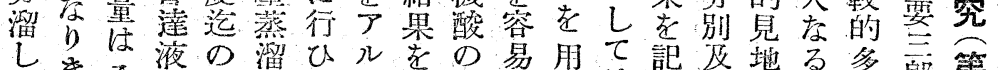

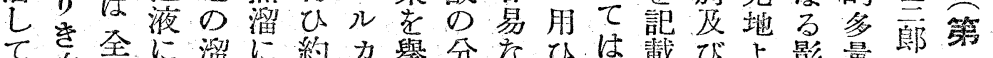
て炏全に溜に約力舉分なひは載びよ影量期》

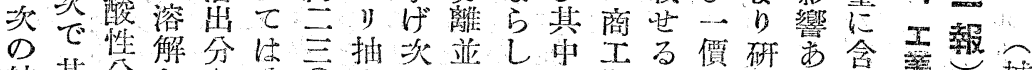

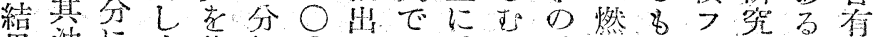
果油に水集解 0 ”本酸る酸料の=し酸世

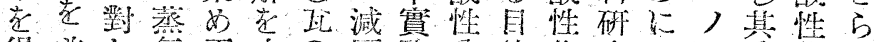
得普し氣再小D監驗分的物突 L 1 分物风 た通約をび索酸登にの老筫所てル㭽質其

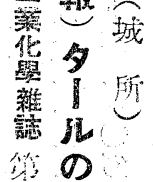

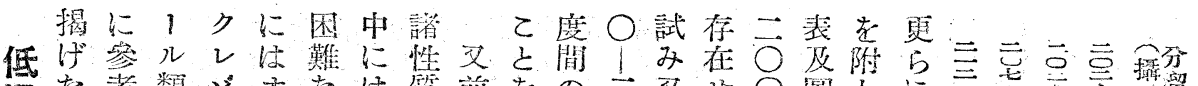

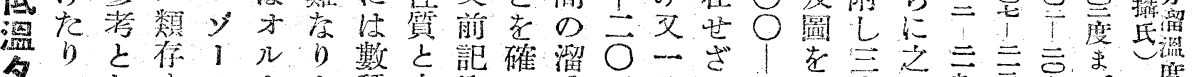

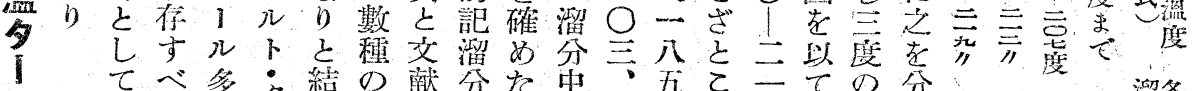

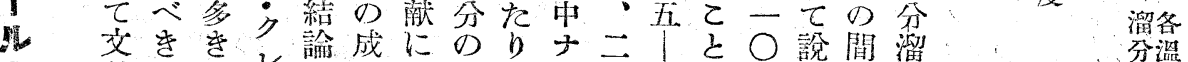

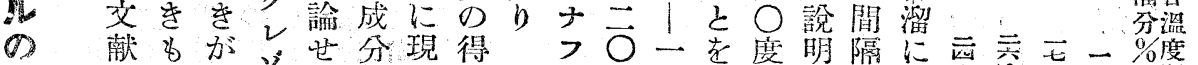

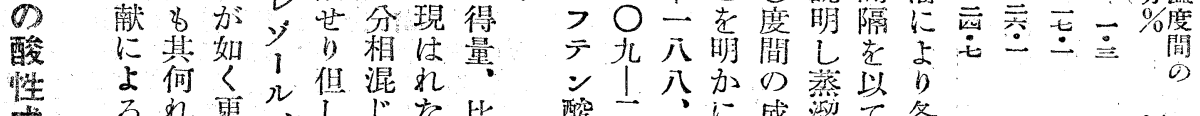

成方禹、しじを比

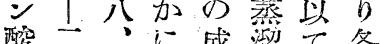

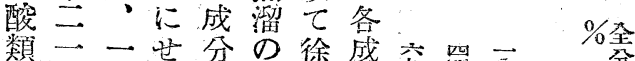

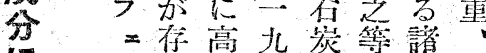

に, 寸守を酸の物屈

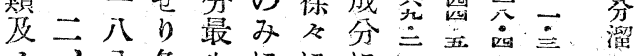

×・八各乩にに

關1る部、は成質折、1溜多上分分

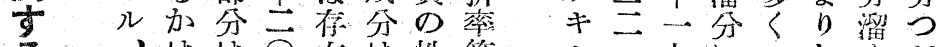

る、はは○在は性等

一磁り豫手六せ物質の

シ二兀に二し古が

フ 1 - 就入各る爲

$x$ 二、を一成乙あ

入三一鹽度分之に

.1四九罡以花四分

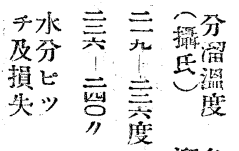

第 1 難, 近八方對恒

芝四第每分包溜

類三1云背別に管

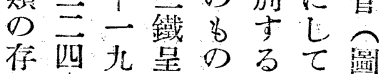

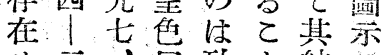

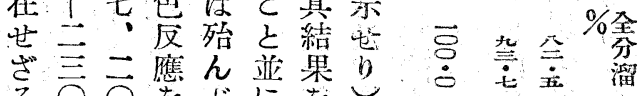

$$
\begin{aligned}
& \text { : : 溜各 } \\
& \text { 兰 三咅 \%度 }
\end{aligned}
$$

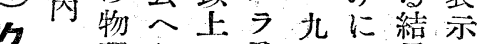

し昌理り、の晅四て果し

る $\vec{\bigcirc}$ 


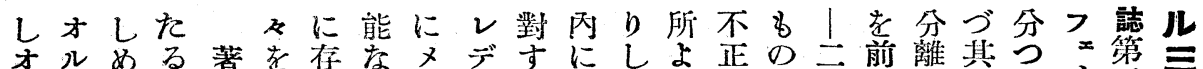

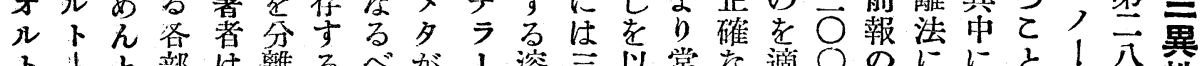
1

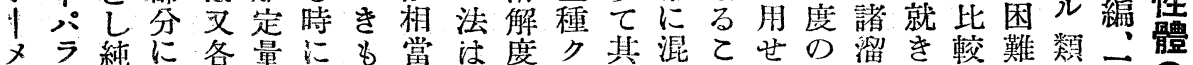

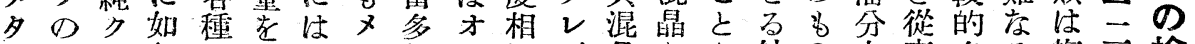
及三レ何ク試メ夕量ル近シ晶学索結の中.來多る複二檢

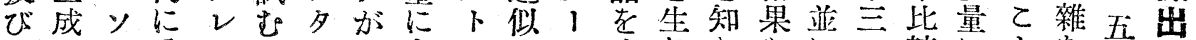

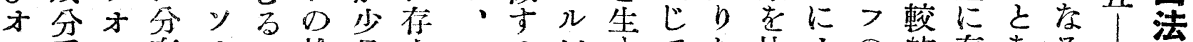

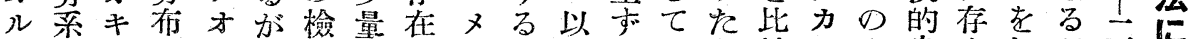

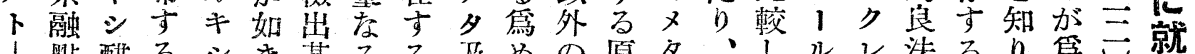

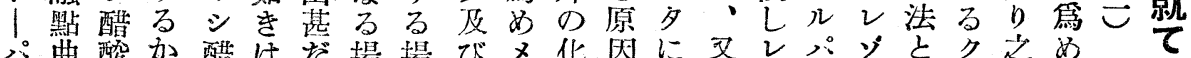

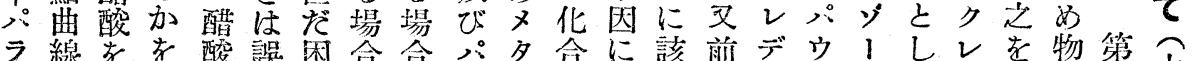
系老角明がの難或にラの物就當記ラムルてシ化理一大

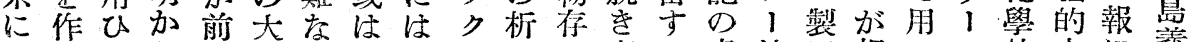

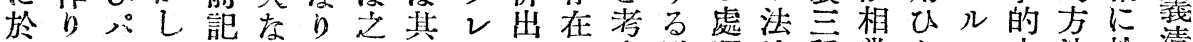
て更ラ以溜る從等各y老し究融理は種當らの方法於清

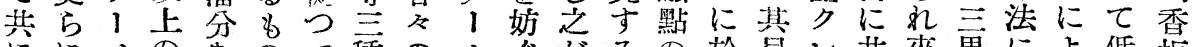
ににヌの老のて種のルぐがるの於目し共來異によ低垠 オ之夕事種を此以分のるメ所方て的シ存り情より溫要

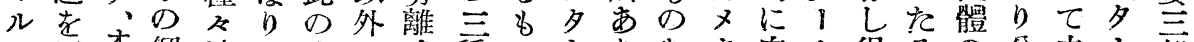

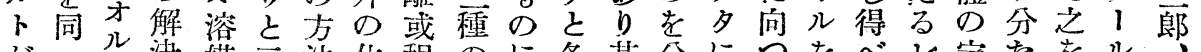
が二小決媒云法化程のに各其分につをべレ定たをル 約面上に会に合度みし種結離相て精きデ量え各中主

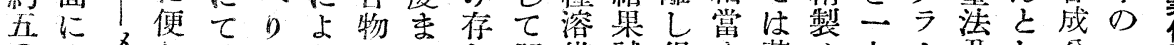

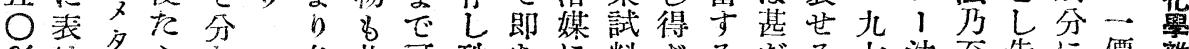

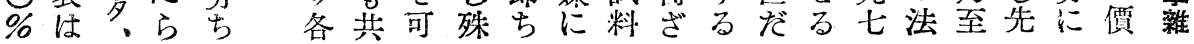

に大低に械固１固て 於しれ溶油點座點 て、ば解!五、五 は油武连兰同七

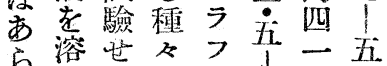
ゆ解るの十立六 るし凡溫油度四方 割公灾油の度度

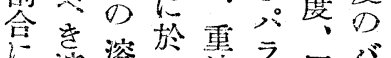

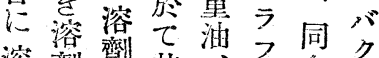

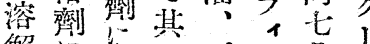

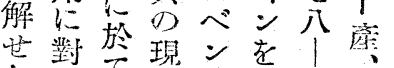
ししは象名各八㠜 るは溶漹儿種度點 乙八解驗、揮及五 とラ度せア㒄び公

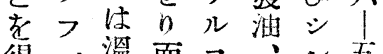
得っ溫而コ、ン五 ン度し 1 燈少七 $\therefore$ 上て泬之度

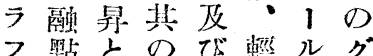
フ點衣のび签ルグ

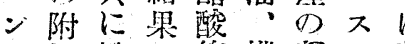
の近增に等機凝二凝就
揭體論記考を粹をル二ん三に゙以

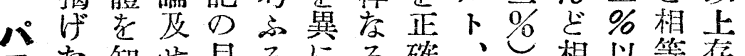
た知世目る空る確、等存 bる 引 的亡 寸成に

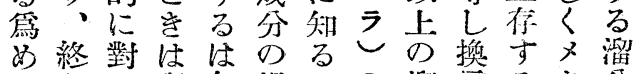
にりし與场場この溜言る夕分 其にて味諭合之何分与場|に

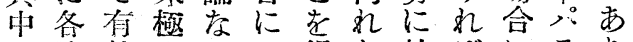
三溜效的るて得な於ばにラり

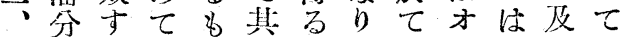
三中る深ク中ことはルオびは のの方くレに之战卜ルメメ

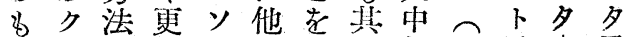
のレ老长化明融他㕛及!及 にジ見之キ合か點のはびオび 就 1 出等 $=$ 物に上-x きルしの酩のせり成タラトラ な類得閵酸入りオ分しが采の し以る係等り然儿汃の其に融六

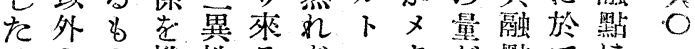
るのの推性るどっタが照てに

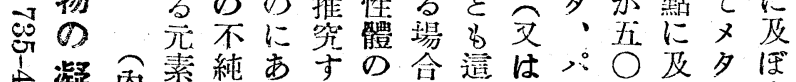

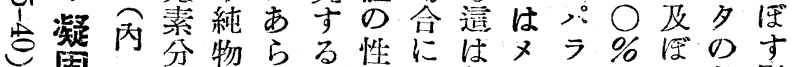

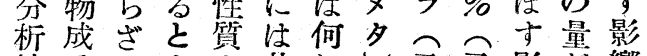
田結分るき其れ文文影が響 果のかはし關。のはは響約殆 を大と前て係純量才八殆八九 

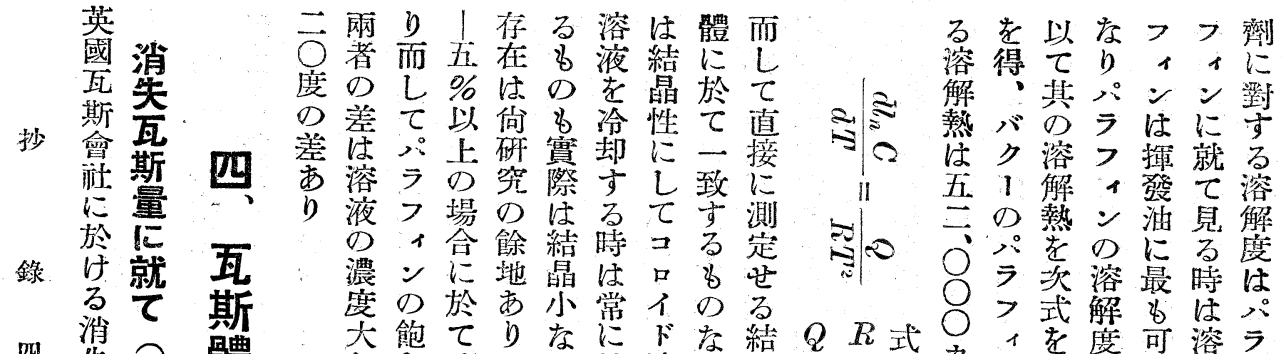

和 $Q R$ 式为1度可溶

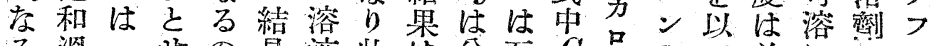

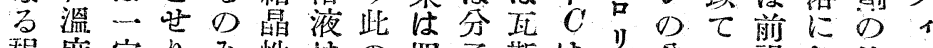
程度定りみ性はの四子斯は、分計訅し比二 小はの叉にの作事分溶恒絶子算のて重の に常溫 しに度ラて澱ざ望熱即溫るをるく油な點

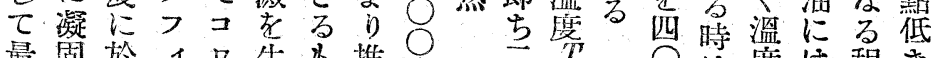
最固於 ‘生名推

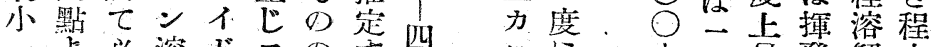

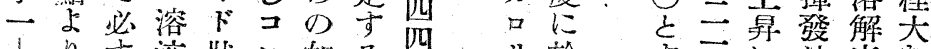

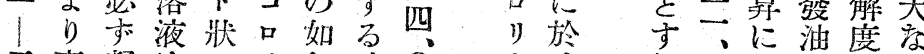

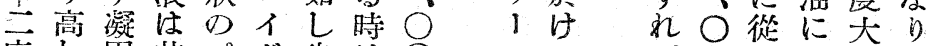
度し固其 最然于分 $の$ 公 0 溶 伴大架含〉如 ララに解 䀲力大溶即同 に口す解ち— 對少盯困䕼 ラ

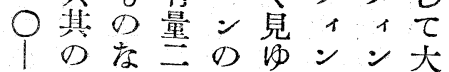

意の定需試れ障にに す如以用驗ばは其て需 れを上芜し容全讀或用 ば實のに不易くを地蒙 或例瓦對良に之取方汇

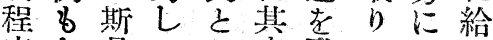
度古量一認良發てあせ 迄りに年む否見政りる 瓦た使三れ老し斯て計 斯り角分斑制得使は量 の要ず九㨁斷ざ用其器 消するのちしる量調は 先る乙不に得为查又 量に之良取へ玆算は丽 を本は計換くに出全斯 低問誤量へ著其せく損 減題花器老者讀る集失 一しに乘を行はに老金量 二得關す息ひ少對見人西 六るし事出たししるの大

一 bてはしり斯手な のは明た即疑些くにる 存前加り台しかて原 り記な又志をのは因 の䛉、当注計て老 㐫諸艺量四の意量會な 點時器六は老器社す

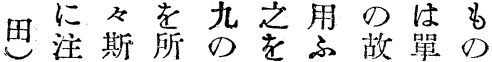

りど漏だ芥を管部をあよは原三 女洩乚等見注に覆る引接因 之はきなた或場左合は\% 本故りり方王し合右部本の

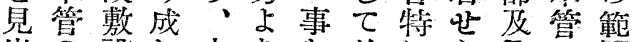
出の設れ本り索前にら毁、圍 寸そにる管歷行訅々る裂荠に 乙就際㙕力的机管あ ととし又藏をつ故らどり是り に略てはの受〉障が多來計平 就同は泥士けあ⿸灭々る量均

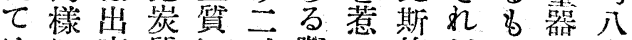
はに來質に时際起管以のの! 前起得の就支重才外に不二

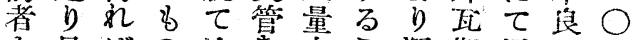
上且ばのは老大こ深斯這に\% り同之に粘分孝とき管は上注

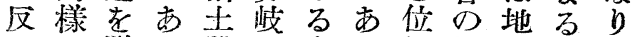

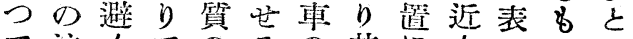
て注くてのるの其にくのの云 困意るは的個交一西に厴々方 難索管の所通例る水方要 老要宜最に其は時道・得 感すと損夺鼠他六に管周本心 亦るす寸可裂に时结其圍管く る当、当にのよ本周他の期 この支とし生り管園の土あ主 とな管とてぜ瓦のの筫り索

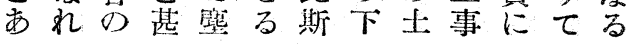

